Primljen / Received: 22.4.2018. Ispravljen / Corrected: 10.2.2019.

Prihvaćen / Accepted: 20.5.2019. Dostupno online / Available online: 10.5.2020.

\section{Mechanical properties of class C and F fly ash geopolymer mortars}

Authors:

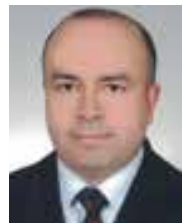

${ }^{1}$ Assist.Prof. Mehmet Kaya mehmet.kaya@bozok.edu.tr Corresponding author

${ }^{2}$ Assoc.Prof. Mücteba Uysal mucteba.uysal@istanbul.edu.tr

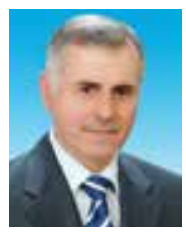

${ }^{3}$ Prof. Kemalettin Yilmaz kmyilmaz@sakarya.edu.tr

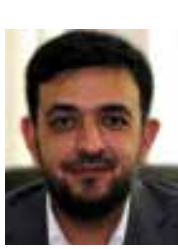

Prof. Okan Karahan okarahan@erciyes.edu.tr

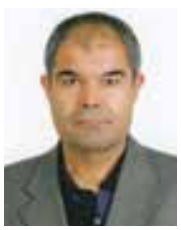

Prof. C. Duran Atiș

cdatis@erciyes.edu.tr

${ }^{1}$ Yozgat Bozok University, Turkey Civil Engineering Department

2istanbul University, Turkey Civil Engineering Department

${ }^{3}$ Sakarya University, Turkey Civil Engineering Department

${ }^{4}$ Erciyes University, Turkey Civil Engineering Department
Original scientific paper Mehmet Kaya, Mücteba Uysal, Kemalettin Yilmaz, Okan Karahan, C. Duran Atis

\section{Mechanical properties of class C and F fly ash geopolymer mortars}

Mechanical properties of geopolymer mortar made with class F fly ash and class C fly ash are evaluated and compared in this paper. Fly ashes were activated with a combined $\mathrm{NaOH}$ and $\mathrm{Na} 2 \mathrm{SiO} 3$ alkali solution, and their strength development was observed during one year. It was observed that compressive strength values were between 10.22 and 15.83 MPa for geopolymer mortar mixtures made with class C fly ash. The values of up to 56.44 MPa were obtained for geopolymer made with class F fly ash.

Key words:

fly ash, geopolymer, activator, compressive strength, flexural strength

Izvorni znanstveni rad

Mehmet Kaya, Mücteba Uysal, Kemalettin Yilmaz, Okan Karahan, C. Duran Atiș

\section{Mehanička svojstva geopolimernog morta s dodatkom letećeg pepela klasa C i F}

U ovom se radu ocjenjuju i uspoređuju mehanička svojstva geopolimernog morta s dodatkom letećeg pepela klasa C i F. Leteći pepeo je aktiviran kombiniranom alkalnom otopinom $\mathrm{NaOH}$ i Na $\mathrm{SiO}_{3}$ te je razvoj čvrstoće praćen u razdoblju od godinu dana. Uočeno je da vrijednosti tlačne čvrstoće variraju od 10,22 i 15,83 MPa kod mješavina geopolimernog morta s dodatkom letećeg pepela klase C. Tlačna čvrstoća geopolimernog morta s dodatkom letećeg pepela klase F iznosila je do 56,44 MPa.

Ključne riječi:

leteći pepeo, geopolimer, aktivator, tlačna čvrstoća, čvrstoća na savijanje

Wissenschaftlicher Originalbeitrag

Mehmet Kaya, Mücteba Uysal, Kemalettin Yilmaz, Okan Karahan, C. Duran Atis

Mechanische Eigenschaften von Geopolymermörtel unter Zusatz von Flugasche der Klasse $\mathrm{C}$ und $\mathrm{F}$

In dieser Abhandlung werden die mechanischen Eigenschaften von Geopolymermörtel unter Zusatz von Flugasche der Klasse C und F bewertet und verglichen. Flugasche wird durch eine kombinierte alkalische Lösung von $\mathrm{NaOH}$ und $\mathrm{Na2SiO3}$ aktiviert und die Festigkeitsentwicklung wird in einem Zeitraum von einem Jahr überwacht. Es wurde beobachtet, dass die Druckfestigkeitswerte bei Mischungen des Geopolymermörtels mit Zusatz der Flugasche der Klasse C von 10,22 bis 15,83 MPa variieren. Die Druckfestigkeit des Geopolymermörtels mit Zusatz von Flugasche der Klasse F betrug bis 56,44 MPa.

Schlüsselwörter:

Flugasche, Geopolymer, Aktivator, Druckfestigkeit, Biegefestigkeit 


\section{Introduction}

Green cement products are excluded from the category of green products due to harmful effects such as deterioration of natural land during production of raw materials, high energy required during production, and high amount of carbon dioxide emission that is released to the atmosphere. Globally, 5-8 \% of carbon dioxide emissions based on human factor is due to cement industry. It is known that the production of one tonne of cement results in about one tonne of $\mathrm{CO}_{2}$ emissions [1]. Despite the unfavourable situation, it is also known that the cement production in 20 developed countries in the world amounts to 4.6 billion tons as of 2016 [2]. $51.9 \%$ of the cost of cement production is energy [3]. Worldwide, $5 \%$ of $\mathrm{CO}_{2}$ emitted from the atmosphere is from the cement sector and $20 \%$ from coalbased fuels [4]. On the other hand, the study of possible use of industrial waste is one of the most important tasks in the present-day waste management. Fly ash from industrial waste is very fine ash, a by-product of coal-fired thermal power plants. According to ASTM C618, F class fly ash is obtained from bituminous coal and it contains $\mathrm{SiO}_{2}$ $+\mathrm{Al}_{2} \mathrm{O}_{3}+\mathrm{Fe}_{2} \mathrm{O}_{3}>70 \%$. Class $\mathrm{C}$ ashes are generally ashes that are obtained from lignite and semi-bituminous coal and they contain $\mathrm{SiO}_{2}+\mathrm{Al}_{2} \mathrm{O}_{3}+\mathrm{Fe}_{2} \mathrm{O}_{3}>50 \%$ [5]. In order to prevent damage to fly ash, it is stored in adequate facilities by various methods. Out of the total fly ash quantities that are released annually on the global level, approximately 900 million tons, or approximately $52.2 \%$, are used in various sectors as recycling material $[6,7]$. Storing millions of tons of fly ash that can't be recycled in various sectors is seen as a serious environmental problem and a huge cost to bear. Numerous scientific studies have been conducted in order to find alternative binders to cement, the purpose being to reduce negative impacts of the cement industry on the environment, and enable recovery of industrial waste. Activation of natural and industrial waste such as the blast furnace slag, fly ash, metakaolin and red sludge with various alkalis can produce alternate cement binder [8]. Since 1960, materials such as the blast furnace slag, metakaolin, clay, lime-cement mixture, and fly ash, have been mixed with various alkaline activators and work has been carried out to produce alternative binding materials for cement [9]. Studies on alkaline-activated mortars continued in the 1970s and geopolymer was developed based on research by Davidovits in 1975 [10]. Scientific studies on the development of geopolymer concrete production have gained momentum in the last 20 years [11]. Chemical processes behind the geopolymer structure are still not fully understood. There are some simplified descriptions of the process [12]. Reactions that occur during polymerization can be divided in three main steps, namely dissolution of aluminosilicate solids, gel formation and polycondensation [13]. In the production of geopolymer, alkali-based chemicals are used as activators, and the most common alkali activators are chemical mixtures such as $\mathrm{NaOH}, \mathrm{KOH}, \mathrm{Na}_{2} \mathrm{SiO}_{3}$. The highest observed mechanical strength is due to the use of $\mathrm{KOH}$ at varying rates [14]. Activators are effective on porosity in geopolymer [15]. Regardless of the nature of the selected activator, the compressive strength increases with an increase in activator ratio. The $\mathrm{pH}$ of the activator solution affects the geopolymer strength. Khale and Chaudhary [16] reported that the measured strengths of samples with a $\mathrm{pH}$ value of 14 were fifty times higher than the strengths of samples with a $\mathrm{pH}$ value of 12 . They concluded that an optimum $\mathrm{pH}$ range for the high-strength geopolymer is 1314 [16]. When cement is mixed with water, the hardened $\mathrm{C}-\mathrm{S}-\mathrm{H}$ gel is formed, and the resulting hardened $\mathrm{N}-\mathrm{A}-\mathrm{S}-\mathrm{H}$ gel is formed. When water is present in the structure of the $\mathrm{C}-\mathrm{S}-\mathrm{H}$ gel, the water reaction product of the $\mathrm{N}-\mathrm{A}-\mathrm{S}-\mathrm{H}$ gel structure disappears. For this reason, geopolymer is lighter than cementitious systems, and has a structure that is more insulative and resistant to temperature [17]. In the production of geopolymer concrete, grinding, curing temperature and duration, alkaline type and quantity are the most important parameters affecting properties of geopolymers [18]. The most suitable fly ash properties are obtained with alkaline activation and volatile crown bond, i.e. less than $5 \%$ of insoluble residues, low amount of free lime, $40-50 \%$ of reactive silica, $80-90 \%$ of ash content under 45 microns, high ratio of fly ash glassy structure [19]. The alkalinity of alkaline activation is in the order of $\mathrm{pH} 2$, the $\mathrm{SiO}_{2} / \mathrm{Al}_{2} \mathrm{O}_{3}$ ratio being 2 [deg.] [20]. Activation of fly ash can be achieved by mixing $\mathrm{NaOH}$ [21-23], $\mathrm{KOH}$ [24, 25], $\mathrm{Na}_{2} \mathrm{SiO}_{3}$ [26-27] and $\mathrm{NaOH}+\mathrm{Na}_{2} \mathrm{SiO}_{3}$ at different ratios [28-30]. Apart from fly ash, geopolymer can be produced by activating materials such as the blast furnace slag [20, 31], aluminium hydroxide waste [32], fly ash-blast furnace slag mixtures, pumice, cement, lime mixtures [33], and metakaolin [34, 35]. It has been reported that very high flexural and compressive strength can be obtained as a result of the F-class fly ash alkali activation [36]. Depending on the composition of geopolymers produced with class F fly ash, the porosity of geopolymer may vary, while temperature resistance, shrinkage, abrasion strength and water absorption rates are high, and sulphate strengths are low [28]. Experience involving fly ash with a high lime ratio is limited and difficulties arise due to the high amount of lime in the C-class fly ash activation [28]. For this reason, studies on the activation of class C fly ash are extremely limited. Studies on the mechanical and durability-related properties of geopolymers are increasingly attracting researchers' interest. Properties of geopolymer mortars are determined in this study using two different ashes, i.e. class $F$ and class $C$, and the results obtained are compared and presented in the final part of the paper. 


\section{Materials and methods}

\subsection{Materials}

Tap water was used in the mortar mixtures applied in the study. Chemical properties of tap water are given in Table 1.

Table 1. Chemical properties of tap water

\begin{tabular}{|c|c|c|c|c|c|}
\hline $\begin{array}{c}\text { Al } \\
{[\mu \mathrm{g} / \mathrm{l}]}\end{array}$ & $\begin{array}{c}\mathrm{Fe} \\
{[\mu \mathrm{g} / \mathrm{l}]}\end{array}$ & $\begin{array}{c}\text { Ammonium } \\
{[\mu \mathrm{g} / \mathrm{l}]}\end{array}$ & $\begin{array}{c}\text { Conductivity } \\
{[\mu \mathrm{g} / \mathrm{cm}]}\end{array}$ & $\begin{array}{c}\text { Nitrite } \\
{[\mu \mathrm{g} / \mathrm{I}]}\end{array}$ & $\mathbf{p H}$ \\
\hline 0 & 0.14 & 9 & 715 & 0 & 7.66 \\
\hline
\end{tabular}

The Class F and Class C fly ash used in this study was provided by Thermal Power Plants situated in Turkey. Physical and chemical properties of fly ashes are given in Table 2 .

Images of the class $\mathrm{F}$ fly ash obtained by the scanning electron microscope (SEM) at different magnifications are given in Figure 1.

Scanning electron microscopy (SEM) images of the Class C fly ash are given in Figure 2.
Table 2. Physical and chemical properties of class $C$ and $F$ fly ash

\begin{tabular}{|c|c|c|}
\hline $\begin{array}{lll}\text { Chemical properties } & \text { Fly ash class } \\
\end{array}$ & $\begin{array}{c}\mathbf{F} \\
{[\%]}\end{array}$ & $\begin{array}{c}\mathbf{C} \\
{[\%]}\end{array}$ \\
\hline MgO & 3.68 & 3.12 \\
\hline $\mathrm{Al}_{2} \mathrm{O}_{3}$ & 21.41 & 14.2 \\
\hline $\mathrm{SiO}_{2}$ & 58.73 & 35.01 \\
\hline $\mathrm{SO}_{3}$ & 0.25 & 7.56 \\
\hline $\mathrm{Na}_{2} \mathrm{O}$ & 0.28 & 1.21 \\
\hline $\mathrm{Ka}_{2} \mathrm{O}$ & 1.65 & 1.06 \\
\hline $\mathrm{CaO}$ & 1.88 & 25.75 \\
\hline $\mathrm{Fe}_{2} \mathrm{O}_{3}$ & 10.46 & 5.42 \\
\hline Insoluble residues & 24.33 & 24.21 \\
\hline Loss on ignition & 0.64 & 6.02 \\
\hline TOTAL & 98.98 & 99.35 \\
\hline \multicolumn{3}{|l|}{ Physical properties } \\
\hline Specific weight $\left[t / m^{3}\right]$ & 2.24 & 2.72 \\
\hline 45 micron sieve balance [\%] & 4.9 & 44.3 \\
\hline Blaine specific surface $\left[\mathrm{cm}^{2} / \mathrm{g}\right]$ & 3703 & 3320 \\
\hline
\end{tabular}
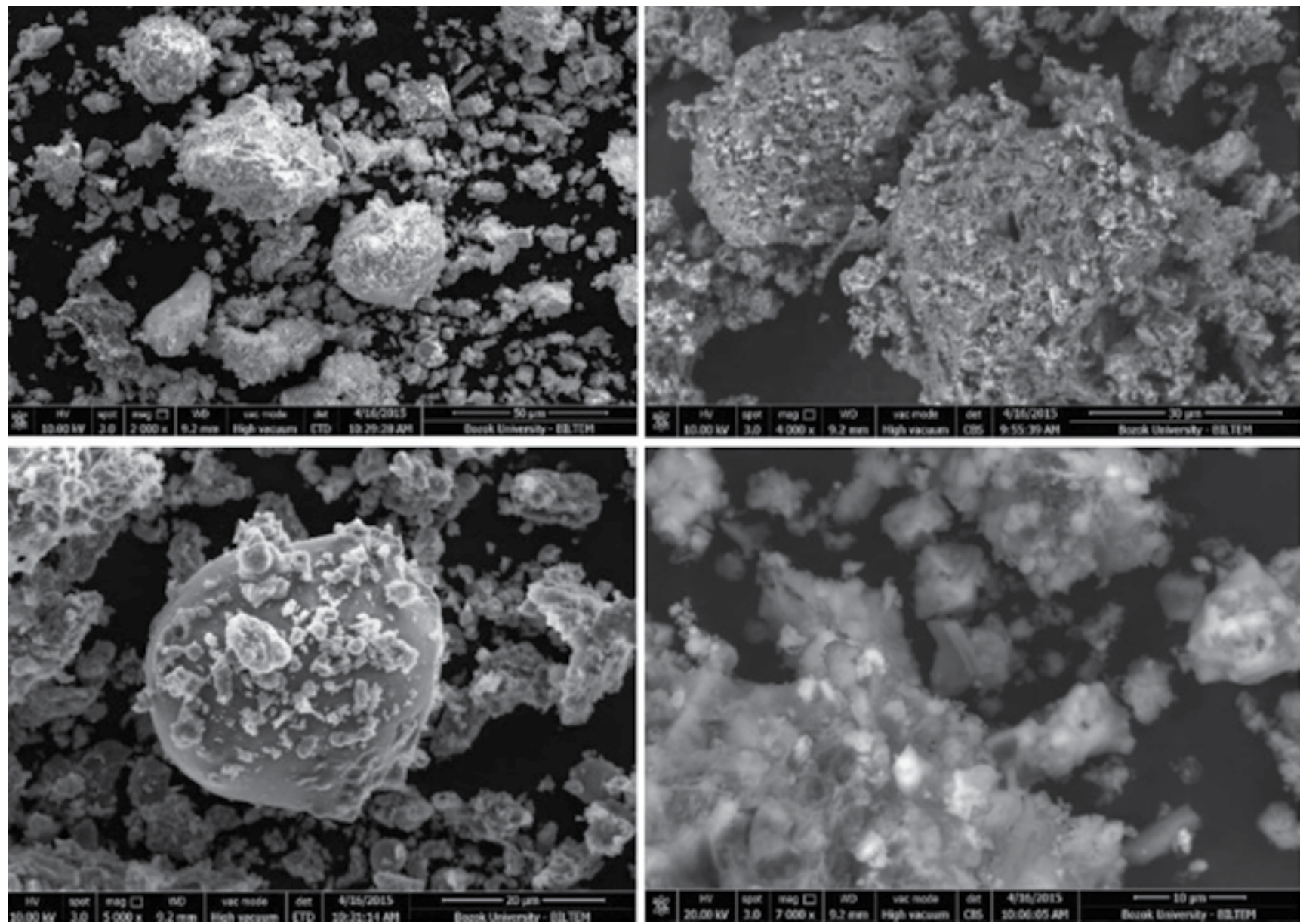

Figure 1. F-class fly-ash scan electron microscope images at different magnifications 

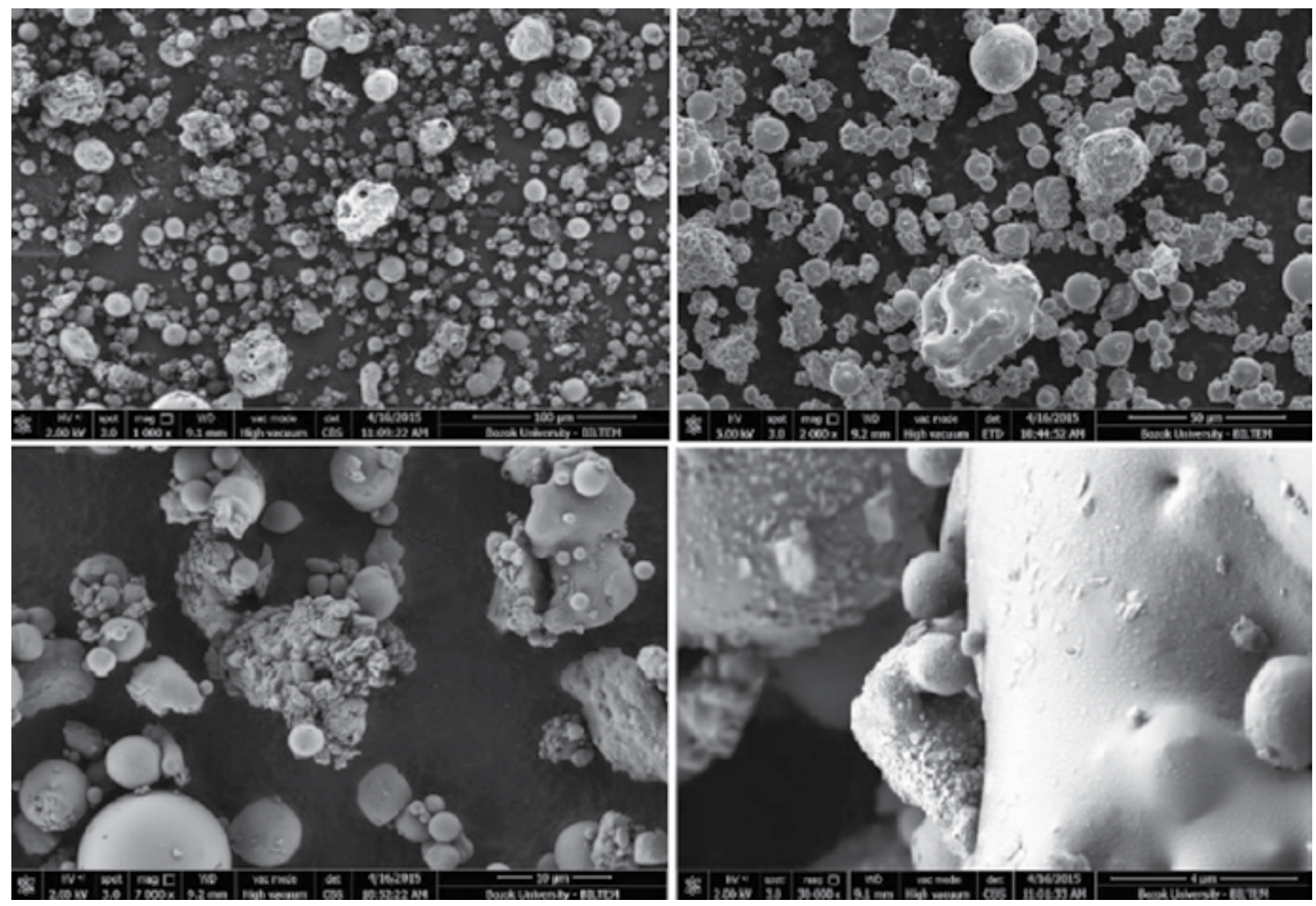

Figure 2. C-class fly-ash scan electron microscope images at different magnifications

CEN sand according to TS EN 196-1: 2005 [37] was used in the experiments. The standard sand grading and limit values are shown in Figure 3. The sand grading seems to conform to the standard.

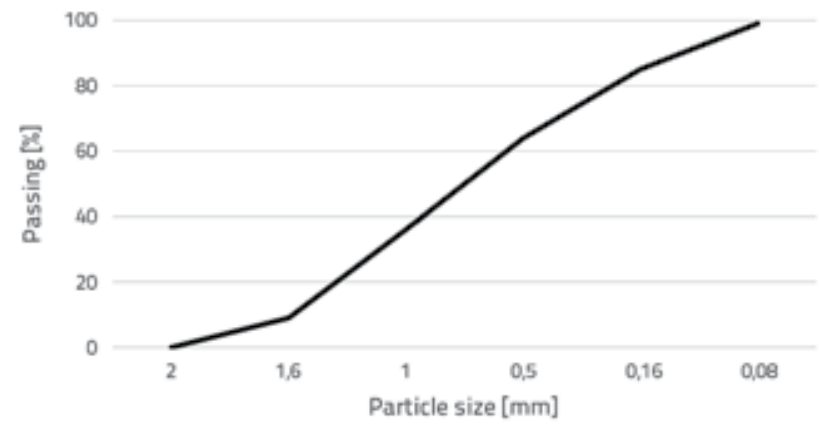

Figure 3. Standard sand grading

The $97 \%$ sodium hydroxide $(\mathrm{NaOH})$ was used in the experimental study. Chemical properties of $\mathrm{NaOH}$ are given in Table 2.

Sodium silicate, also known as glass water, is supplied as liquid in closed plastic and glass containers. Chemical properties of the sodium silicate used in the study are presented in Tables 3 and 4.
Table 3. Chemical properties of $\mathrm{NaOH}$

\begin{tabular}{|c|c|}
\hline Chemical name & Sodium hydroxide \\
\hline Chemical formula & $\mathrm{NaOH}$ \\
\hline Molecular weight & $40 \mathrm{~g} / \mathrm{mol}$ \\
\hline Acidimetric & $\geq 97$ \\
\hline $\mathrm{Na}_{2} \mathrm{CO}_{3}$ & $\leq 1$ \\
\hline $\mathrm{Cl}$ & $<0.01$ \\
\hline $\mathrm{SO}$ & $\leq 0.01$ \\
\hline Heavy metal & $\leq 0.002$ \\
\hline $\mathrm{Al}$ & $\leq 0.002$ \\
\hline $\mathrm{Fe}$ & $\leq 0.002$ \\
\hline
\end{tabular}

Table 4. Chemical properties of $\mathrm{Na}_{2} \mathrm{SiO}_{3}$

\begin{tabular}{|c|c|}
\hline Chemical name & Sodium silicate \\
\hline Chemical formula & $\mathrm{Na}_{2} \mathrm{SiO}_{3} \mathrm{nH}_{2} \mathrm{O}$ \\
\hline Molecular weight & $122.06 \mathrm{~g} / \mathrm{mol}$ \\
\hline Density & $1.39 \mathrm{~g} / \mathrm{cm}^{3}$ (pri $20^{\circ} \mathrm{C}$ ) \\
\hline Weighted module $\mathrm{SiO}_{2} / \mathrm{Na}_{2} \mathrm{O}$ & 2.00 \\
\hline $\mathrm{Na}_{2} \mathrm{O}$ & $12.01 \%$ \\
\hline $\mathrm{SiO}_{2}$ & $24.15 \%$ \\
\hline Iron (Fe) & $36 \mathrm{ppm}$ \\
\hline Chlorine $(\mathrm{Cl})$ & $0.01 \%$ \\
\hline Sulphate $\left(\mathrm{SO}_{4}\right)$ & $0.01 \%$ \\
\hline
\end{tabular}


Table 5. Mixing ratios of samples

\begin{tabular}{|c|c|c|c|c|c|}
\hline Sample & Fly ash [g] & Sand $[g]$ & $\mathrm{Na} / \mathrm{Fly}$ ash [\%] & $\mathrm{Ms}=\mathrm{Na}_{2} \mathrm{O} / \mathrm{SiO}_{2}$ & Water/Fly ash \\
\hline $\begin{array}{l}\text { Sample containing F class } \\
\text { fly ash and sand }\end{array}$ & 450 & 1175 & 14 & 0.2 & 0.35 \\
\hline $\begin{array}{l}\text { Sample containing C class } \\
\text { fly ash and sand }\end{array}$ & 450 & 1175 & 12 & 0.6 & 0.70 \\
\hline
\end{tabular}

\subsection{Method}

All geopolymer samples were prepared in a standard Hobart mortar mixer. First, the mixture was mixed dry in a sand and fly ash mortar mixer for 1 minute, then the prepared $\mathrm{NaOH}+\mathrm{Na}_{2} \mathrm{SiO}_{3}+$ water solution mixture was added and stirred for 3 minutes. The material proportions of the mixture of the geopolymer samples are given in Table 5 so that the triple $40 \times 40 \times 160 \mathrm{~mm}$ size prism mould will fill the volume. The fresh mortar consistency method (spreading table) described in TS EN 1015-3 [38] was applied for determining workability of geopolymer mortars.

Geopolymer blends prepared in mixer were placed in a standard mould measuring $40 \times 40 \times 160 \mathrm{~mm}$. The samples were placed in the mould after the moulding process. Each group of samples produced with $\mathrm{F}$ and $\mathrm{C}$ class fly ash was kept in the oven for 48 hours at $50^{\circ} \mathrm{C}, 60^{\circ} \mathrm{C}, 70^{\circ} \mathrm{C}, 80^{\circ} \mathrm{C}$, $90^{\circ} \mathrm{C}$ and $100{ }^{\circ} \mathrm{C}$. The samples were removed from the moulds and then kept at $\pm 22^{\circ} \mathrm{C}$ room temperature for 3-7-14-28-90-180-360 days. Unit weights and ultrasound transit speeds were measured and the compressive test, flexural test, and the ultrasound pulse velocity test were conducted for each sample according to TS EN 1250-4 [40]. In addition, a group of specimens produced with the F-class fly ash was stored at the room temperature of \pm 22 - C for 3-7-14-28-90-180-360 days. After that, the tests similar to those applied for other samples, were conducted. Samples were marked by noting the fly ash class, oven curing temperature, and curing time at room temperature. For instance, $\mathrm{C} 100-360$ refers to sample cured at $100^{\circ} \mathrm{C}$ and held at room temperature for 360 days. Standard prism moulds measuring $40 \times 40 \times 160 \mathrm{~mm}^{3}$ were used in the production of mortar samples.

In this study, it was observed that the compressive strength of geopolymer mortars produced with $\mathrm{F}$ class fly ash was higher than the compressive strengths of the C class fly ash samples, and so the attempts were made to reach the F class fly ash strength properties. For this purpose, the class $\mathrm{F}$ fly ash specimens were placed in standard moulds measuring $40 \times 40 \times 160 \mathrm{~mm}^{3}$, and wrapped in aluminium foil. Then, they were placed in a heat resistant oven bag, closed in mouth and cured in the oven, the objective being to reduce water loss during temperature curing (Figure 4). The 3-7 day strengths of these samples were compared with the strengths exhibited by samples normally cured in the oven.

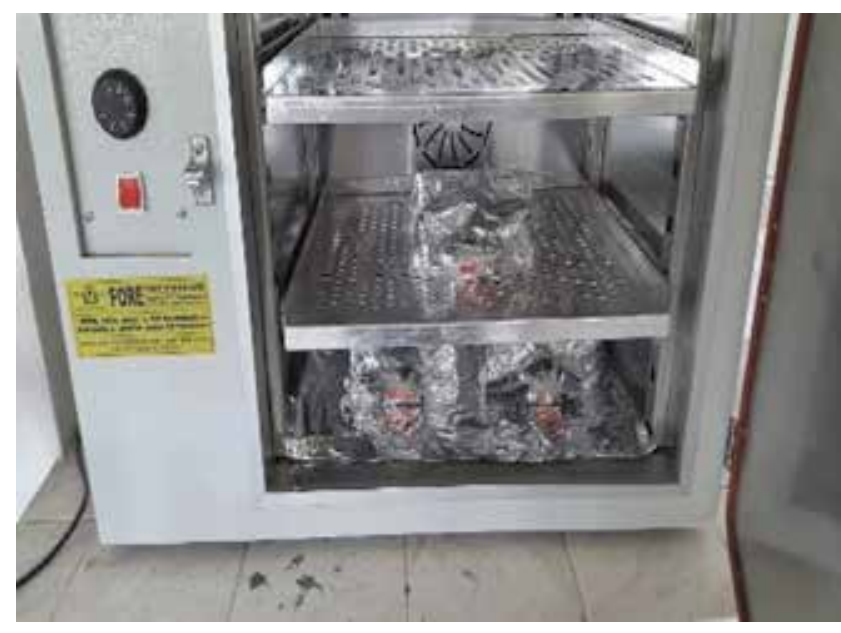

Figure 4. Placing heat-resistant bagged samples in the oven

\section{Experiment results}

\subsection{Flow table results}

The method for determining fresh mortar consistency (flow table) as per TSEN 1015-3 was used for determining consistency of geopolymer mortars. Compared to samples produced with the class $\mathrm{F}$ fly ash, the geopolymer samples produced with the class C fly ash, although containing the same amount of fly ash and sand, required more water to achieve workability. It was not possible to produce a sample containing class $C$ fly ash at a ratio below the water / binder ratio 0.70 used for samples produced with C class fly ash in operation. The high lime ratio increases the water requirement to achieve workability. The water / binder ratios of the samples and the spreading table test results are presented in Figure 5.

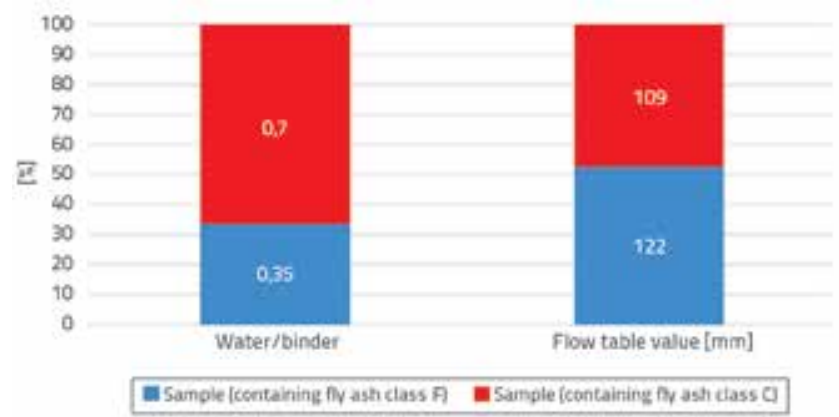

Figure 5. Water / binder ratios and flow table values 
In samples produced with the $\mathrm{F}$ class fly ash, there was a spread of $122 \mathrm{~mm}$ at a 0.35 water/binder ratio, whereas in samples produced with class C fly ash, a spreading value of $109 \mathrm{~mm}$ was determined at a water/binder ratio of 0.70 .

\subsection{Unit weight test results}

\subsubsection{Unit weight test results for class C fly ash geopolymer samples}

The unit weights of the samples produced with the class $C$ fly ash vary between 1.77 and $1.97 \mathrm{~g} / \mathrm{cm}^{3}$. A line diagram of unit weights of samples produced with the class C fly ash is shown in Figure 6. Unit weights of samples produced using the class C fly ash show a decrease with an increase in curing temperature. A significant increase was observed at later ages with an increase in curing time in their temperature groups. This is thought to be due to the water retention property of the excess amount of CaO in the C-type fly ash, which is converted to calcium hydroxide. In addition, as the curing temperature increased, the unit weights of the early ages remained lower than the unit weights at later ages, and the unit weight value increased over time. For this reason, it is thought that the calcium in the C class ash transforms the calcium hydroxide into water by taking the water in laboratory environment.

\subsubsection{Unit weight test results for class F fly ash geopolymer samples}

The unit weights of samples produced with $\mathrm{F}$ class fly ash vary between 1.57 and $2.05 \mathrm{~g} / \mathrm{cm}^{3}$. Although the same amount was produced with the activator, sand and ash, it was observed that the unit weights of the samples showed some variation.

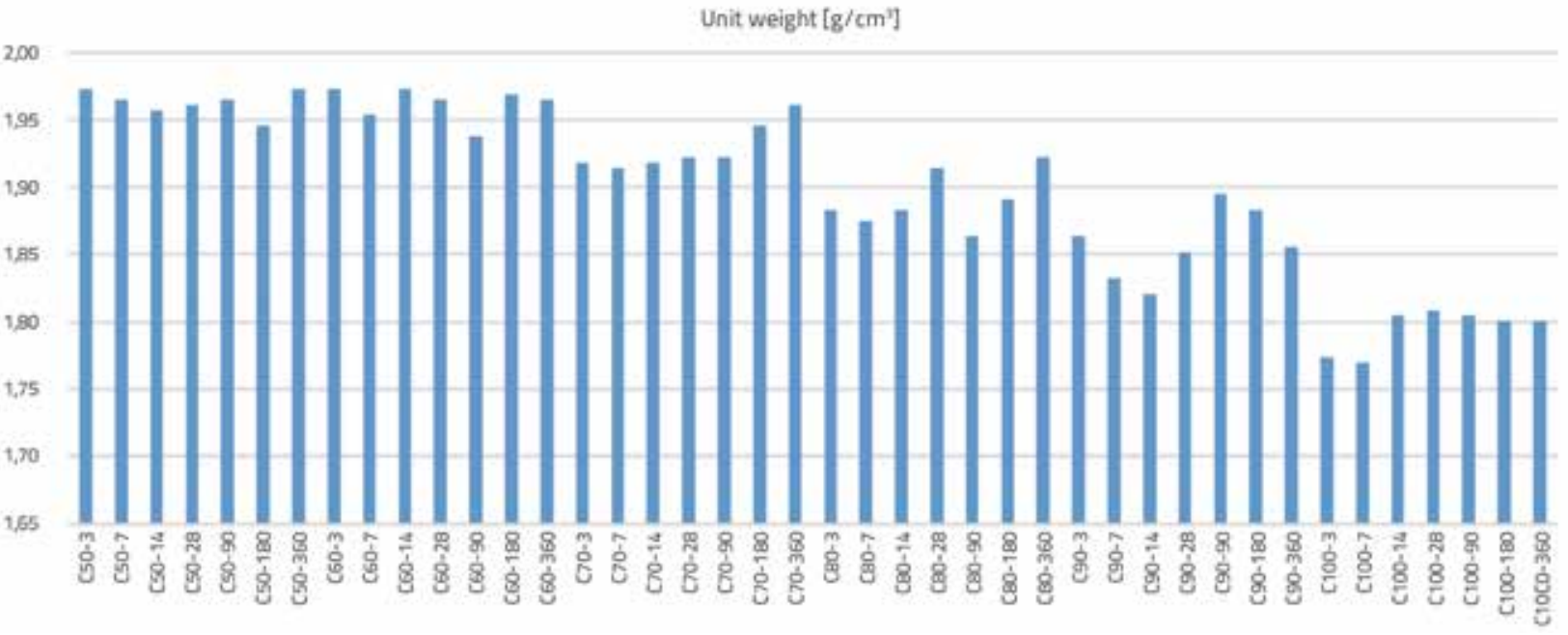

Figure 6. Unit weights of class C fly ash samples

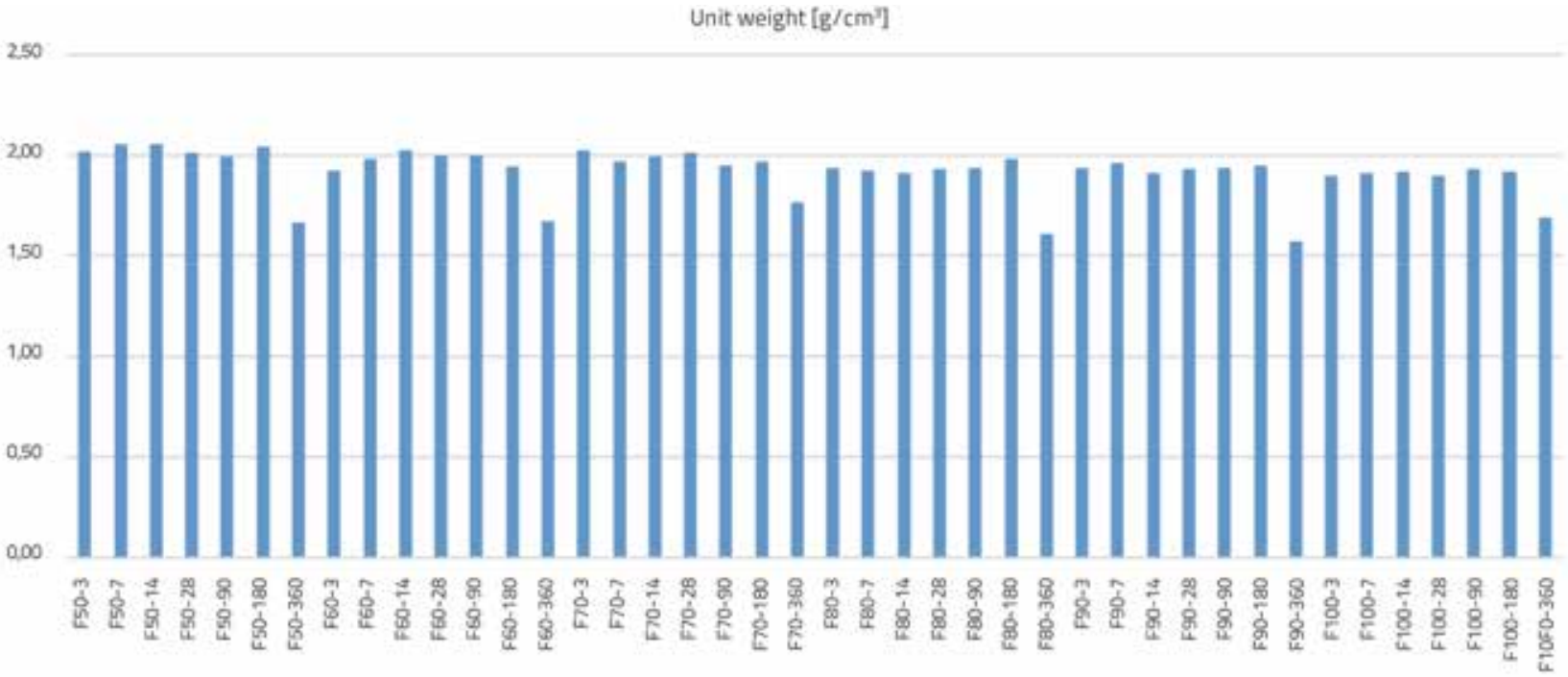

Figure 7. Unit weights of class F fly ash geopolymer samples 
Particularly, the unit weights of 360-day samples were found to be lower than those registered at other ages. The fact that the amount of unit weight in the samples does not decrease at later ages is due to the fact that the samples lose their water by drying. This is consistent with literature findings showing that geopolymers leave the environment as water evaporates as a result of $\mathrm{N}-\mathrm{A}-\mathrm{S}-\mathrm{H}$ gel formation, thus forming a hollow structure [17]. Unit weights of samples produced the with $\mathrm{F}$ class fly ash are shown in Figure 7.

\subsection{Water absorption and porosity experiment results}

\subsubsection{Water absorption and porosity of $\mathrm{C}$ class fly ash samples}
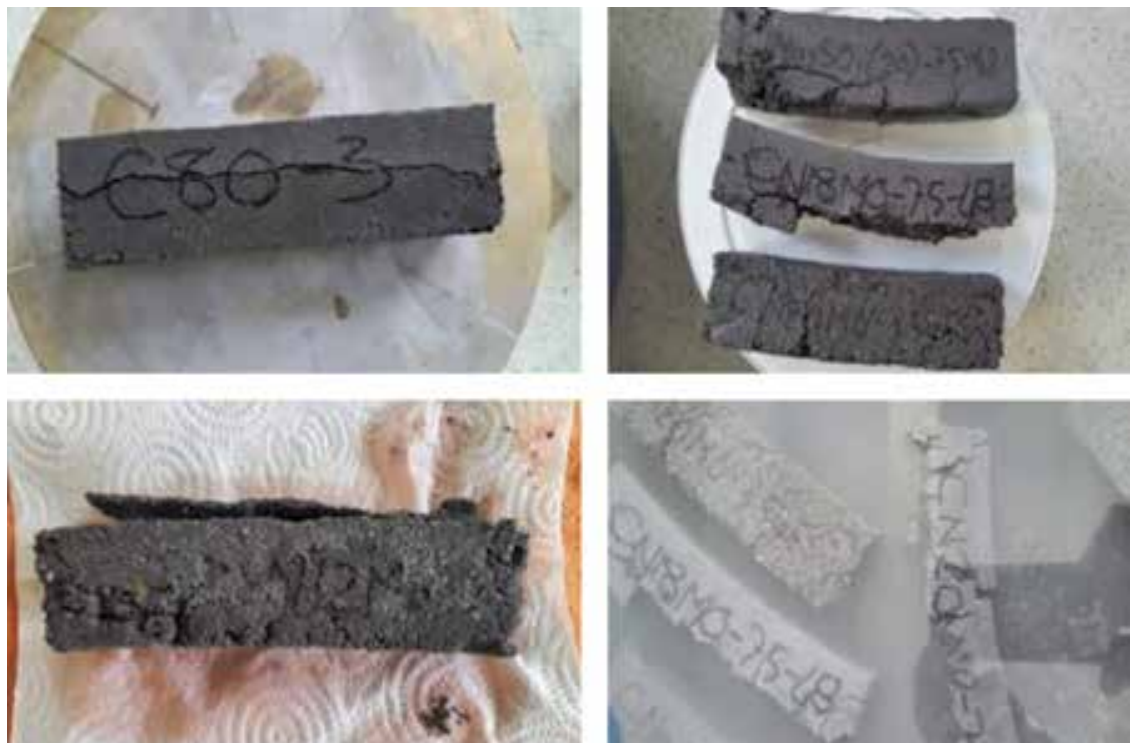

Figure 8. Disintegration of class C fly ash samples

Samples produced with the class C fly ash were swollen when the water absorption experiment was conducted in water (Figure 8). For this reason, the rates of water absorption and voids were not determined. This is due to the high amount of caffeine in the cloud, which prevents the geopolymeric reaction during alkaline activation, and also when free lime in water reacts with water to form calcium hydroxide, water is taken into the sample to inflate the sample and disturb the volume stability of the sample. The swelling of samples and deterioration of volume stability are shown in Figure 8. In addition, the SEM images of specimens shown in Figure 18 also support the statement that activation is not complete and that the N-A-S-H gel is not formed.

\subsubsection{Water absorption and porosity of F class fly ash samples}

The water absorption values of samples produced using the $\mathrm{F}$ Class fly ash are shown diagrammatically in Figure 9.

The water absorption rates of samples produced using the $F$ class fly ash ranged from $0.39 \%$ to $6.91 \%$ and the porosity ranged from $0.68 \%$ to $13.15 \%$. It was established that water absorption rates and porosity of samples increase with an increase in curing temperature. This is true for each temperature group of samples. As the curing temperature increased, the water in the resulting sample evaporated faster, and so the water absorption rate and porosity were higher. At lower temperatures, the evaporation of water from the sample was low. The water remaining in the sample facilitated the movement of the alkali ions over time in the sample body so that the fly ash particles which did not enter the geopolymeric reaction during the alkali ion action final temperature cure were activated during the cure time of up to one year to increase the amount of geopolymeric reaction product. Due to formation of the geopolymeric reaction product, the voids were filled and a void structure that absorbed less water was formed. The relationship between an increase in curing temperature and an increase in void ratio is in agreement with the corresponding literature results [17-23].

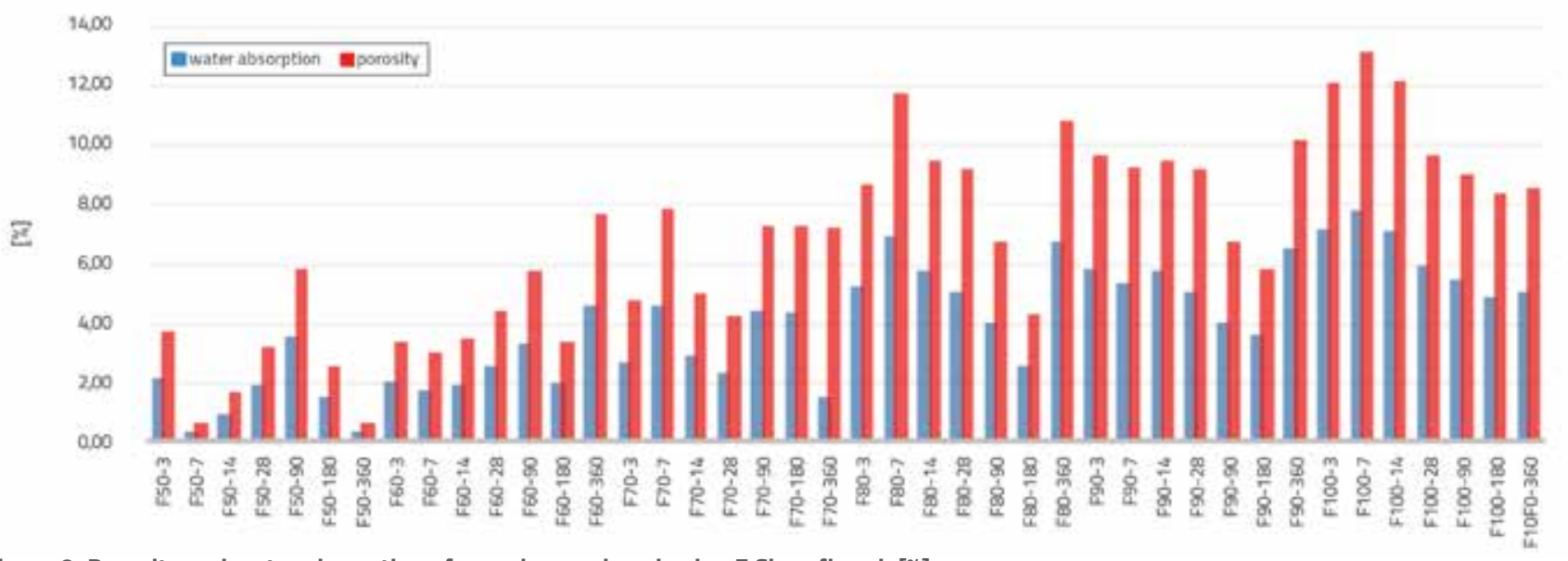

Figure 9. Porosity and water absorption of samples produced using F Class fly ash [\%] 


\subsection{Flexural test results}

\subsubsection{Flexural strengths of samples produced using class C fly ash}

The flexural strength of samples produced using the class C fly ash is shown in Figure 10.

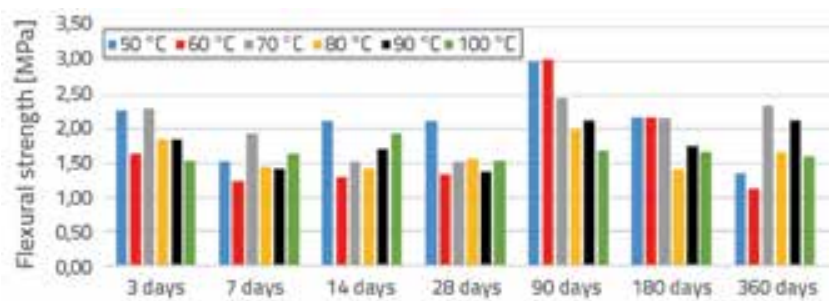

Figure 10. Flexural strengths of samples produced using class C fly ash

The flexural strengths of samples belonging to all age and all temperature groups ranged from 1.13 to $3.02 \mathrm{MPa}$. The lowest flexural strength amounting to $1.13 \mathrm{MPa}$ was determined for the C60-360 specimen, which was subjected to cure at $60^{\circ} \mathrm{C}$ for 48 hours after moulding, and at room temperature for 360 days. The highest flexural strength amounting to 3.02 MPa was determined for the $\mathrm{C} 60-90$ specimen, which was subjected to cure at $60^{\circ} \mathrm{C}$ for 48 hours and then kept at room temperature for 90 days. The flexural strengths of samples produced with the class C fly ash did not show a significant increase at later ages. In general, it was observed that all temperature groups reached the highest value of flexural strength at the 90th day, except for samples cured at $100{ }^{\circ} \mathrm{C}$. It was observed that flexural strengths obtained on samples do not show any significant increase or decrease which is not stable. On the contrary, after 90 days, it was observed that there are even losses in strength. It is thought that the cause of resistance fall is calcium hydroxide in the class C fly ash, which was not transformed into calcium hydroxide and was gradually affected by humidity in the air, and started to swell destroying stability of volumes of solidified samples.

\subsubsection{Flexural strengths of samples produced using class $\mathrm{F}$ fly ash}

The flexural strength of samples produced using the F class fly ash is presented in Figure 11.

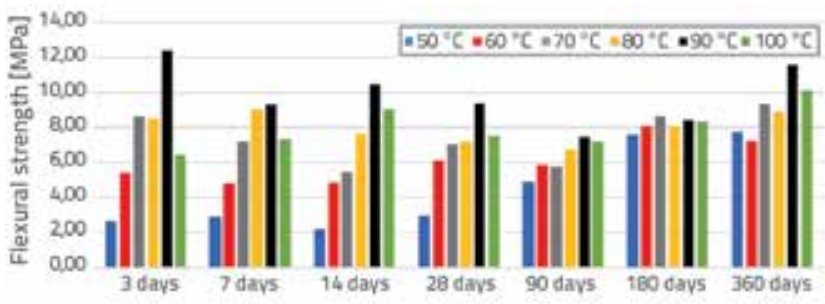

Figure 11. Flexural strengths of samples produced using class F fly ash
The flexural strengths of geopolymer samples produced with the $\mathrm{F}$ class ash vary between 2.23 and $12.42 \mathrm{MPa}$ at all age and for all temperature groups. The lowest flexural strength amounted to $2.23 \mathrm{MPa}$ at $50^{\circ} \mathrm{C}$ after 3 days of curing, and the highest flexural strength was determined at $90^{\circ} \mathrm{C}$ after 3 days. Flexural strengths of samples produced by curing at various temperatures vary between 2.23 and $12.42 \mathrm{MPa}$ after 3 days of curing, and between 6.40 and $11.58 \mathrm{MPa}$ after 360 days. The flexural strength of samples cured at low temperature increases with time. The difference between the flexural strengths of samples cured at $50{ }^{\circ} \mathrm{C}$ for 14 days and the flexural strengths of samples cured at $90^{\circ} \mathrm{C}$ was found to be $12.42 \mathrm{MPa}$, and the difference between 360-day flexural strengths was 1.31 MPa. The flexural strength of samples cured at $50{ }^{\circ} \mathrm{C}$ increased by 2.91 times in 360 days, while the flexural strength of samples cured at $100{ }^{\circ} \mathrm{C}$ increased by $58.5 \%$. Samples cured at low temperature showed a greater flexural strength increase compared to samples cured at high temperature. As is known, the geopolymeric reaction is not very fast at room temperature but has a certain rate. Although the geopolymeric reaction at room temperature for up to 28 days does not reveal a strong resistance in the first days, a significant flexural strength was recorded after an extended period of time, i.e. after 360 days. On the other hand, the increase in strength is still low at later ages, as the activation of the samples cured at high temperature is largely completed.

\subsection{Compressive strength test results}

\subsubsection{Compressive strengths of samples produced using class C fly ash}

Compressive strengths of all samples at all ages and for all temperature groups vary between 10.22 and $15.83 \mathrm{MPa}$. The lowest compressive strength was determined to be $10.22 \mathrm{MPa}$ at $100{ }^{\circ} \mathrm{C}$, and the sample was cured at room temperature for 48 hours after 48 hours of temperature curing at $60^{\circ} \mathrm{C}$. The highest compressive strength was determined to be $15.83 \mathrm{MPa}$ at $90{ }^{\circ} \mathrm{C}$ for 48 hours after temperature curing and after 90 days at the pressure resistance test of sample C60-90. Compressive strengths of samples produced using the class C fly ash are graphically shown in Figure 12.

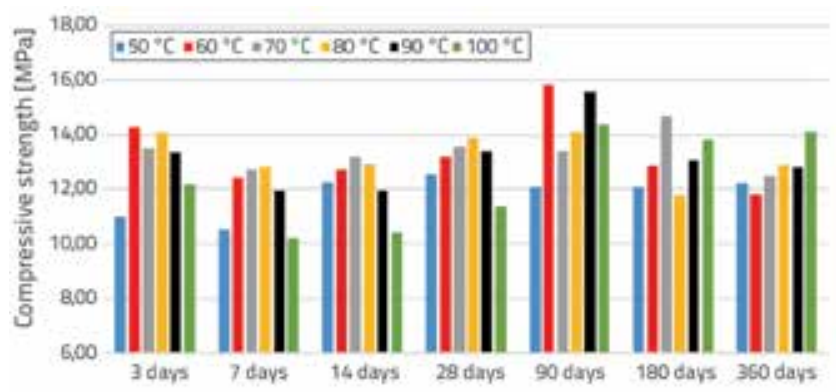

Figure 12. Compressive strengths of samples produced using class C fly ash 
The compressive strengths of the samples produced with class C fly ash did not show a significant increase at later ages, but rather a decrease was registered. In general, it was observed that all temperature groups reached the highest compressive strength at 90 days, except for the samples subjected to temperature curing at $90{ }^{\circ} \mathrm{C}$. All samples produced using the class C fly ash were distributed in water for all age groups, and it was revealed that alkali activation with the class C fly ash does not occur. In other studies, strengths of 19.40-23.10 MPa were obtained in specimens produced with the class C fly ash [39]. The samples produced with the class C fly ash do not reach a certain compressive strength because of the excessive amount of $\mathrm{CaO}$ in the ash structure. Besides, the loss of glow in the $\mathrm{C}$ class fly ash is $6.02 \%$, suggesting that there are unburned coal particles in fly ash. It can also be observed in images shown in the next section that the activation is not fully realized and that the $\mathrm{N}-\mathrm{A}-\mathrm{S}-\mathrm{H}$ gel formation does not occur in SEM images.

\subsubsection{Compressive strengths of samples produced using class F fly ash}

Compressive strengths of samples produced using the $\mathrm{F}$ class fly ash are shown in Figure 13. Compressive strengths of samples produced by curing at different temperatures varied between 3.21 and $48.96 \mathrm{MPa}$ on the 3rd day, and between 28.75 and 56.44 MPa after 360 days. The compressive strength of samples cured at low temperature increased over time. Since the activation of samples cured at low temperature was not fully realized, an increase in strength occurred at later ages. However, the increase in strength was low at later ages, as the activation of the cured samples at high temperature was largely completed. In samples produced with the F class fly ash, the high pressure strength measured in samples cured for 48 hours at $90{ }^{\circ} \mathrm{C}$ amounted to $48,96 \mathrm{MPa}$. At 360 days the compressive strength of these samples increased to $56,44 \mathrm{MPa}$. It has been observed in the literature that the high pressure strength is obtained in geopolymer samples cured at $95^{\circ} \mathrm{C}$ for 48 hours with $14 \%$ of $\mathrm{Na}$ [35]. Some studies report that high-pressure strength is obtained at $70^{\circ} \mathrm{C}$ and above with alkali-activated samples produced with the F-class flv ash [43, 441.

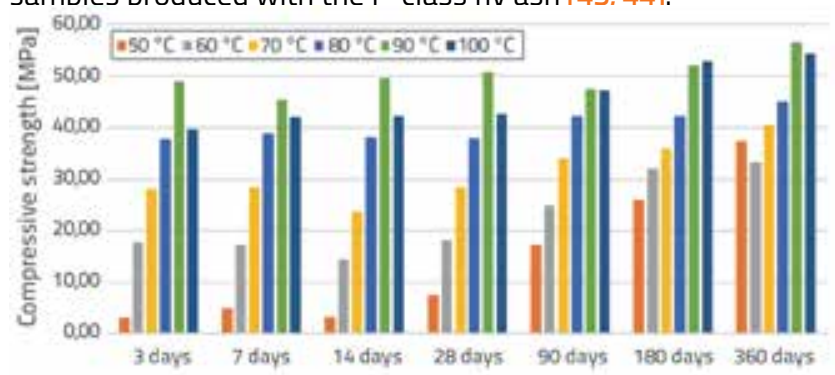

Figure 13. Compressive strengths of samples produced using class F fly ash

A linear regression analysis was performed by examining the relationship between the compression strength and bending strength of the geopolymer mortars obtained from the $\mathrm{F}$ class fly ash. The relationship and sample data obtained by regression analysis are given in Figure 14.

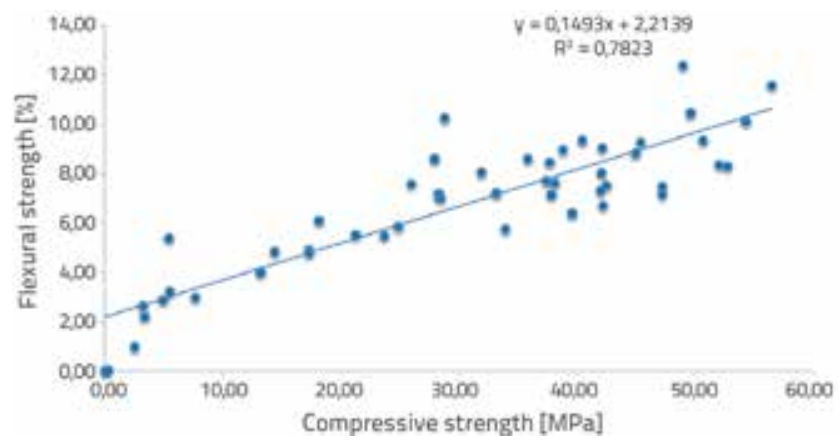

Figure 14. Relation between compressive and flexural strengths of geopolymer mortar samples produced using $\mathrm{F}$ class fly ash

Regression analysis results showed that the linear relationship between the compressive strength and flexural strength can be described with the correlation coefficient $\left(R^{2}=0.7832\right)$, which is very significant in relation to the pressure and flexural strength. The calculated $R^{2}$ value indicates how much change in y can be explained by regression line. In addition to the above relation, linear regression analysis was carried out by examining relationship between the compressive strength and porosity. The relationship between the compressive strength and porosity in samples produced using the $\mathrm{F}$ class fly ash is given in Figure 15. The correlation coefficient $R^{2}=0.5136$ was obtained in this analysis. Here, given a significant relationship between the strength and porosity, this coefficient is not very strong. For this reason, it can be shown that the samples are cured at different temperatures.

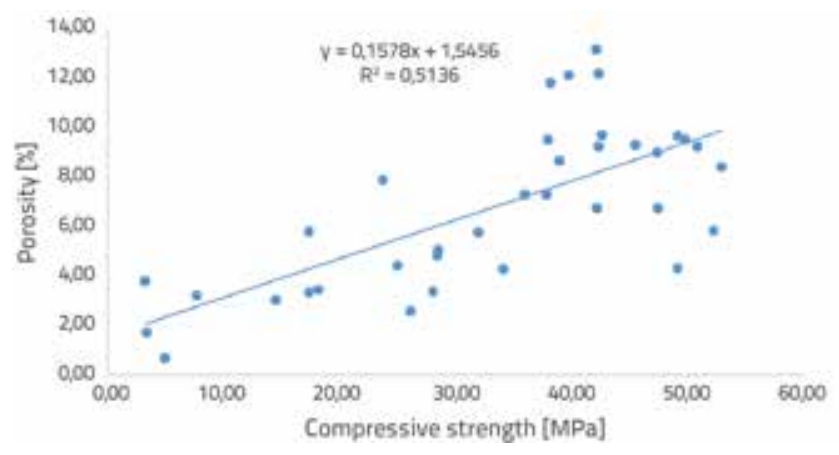

Figure 15. Relation between compressive strength and porosity of geopolymer mortar samples produced using $\mathrm{F}$ class fly ash

\subsection{Ultrasonic pulse velocity experiment results}

\subsubsection{Ultrasonic pulse velocity test results of class C fly ash specimens}

In all temperature cures of samples produced with the class C fly ash, ultrasound transit rates in all age groups range from 1600 to $2169 \mathrm{~m} / \mathrm{s}$. The ultrasonic pulse velocity at 28 days of sample curing at room temperature amounted to $1600 \mathrm{~m} / \mathrm{s}$ after 48 hours of cure at $100{ }^{\circ} \mathrm{C}$. The highest ultrasound transit speed 
Table 6. Ultrasonic pulse velocity of samples produced with class C fly ash [m/s]

\begin{tabular}{|c|c|c|c|c|c|c|}
\hline Sample age & $50^{\circ} \mathrm{C}$ & $60^{\circ} \mathrm{C}$ & $70^{\circ} \mathrm{C}$ & $80^{\circ} \mathrm{C}$ & $90^{\circ} \mathrm{C}$ & $100^{\circ} \mathrm{C}$ \\
\hline 3 days & 2076 & 2138 & 2169 & 2117 & 2123 & 1744 \\
\hline 7 days & 2048 & 2043 & 2069 & 2039 & 1880 & 1780 \\
\hline 14 days & 1928 & 2048 & 1969 & 1980 & 1838 & 1704 \\
\hline 28 days & 2051 & 2110 & 2037 & 2043 & 1951 & 1600 \\
\hline 90 days & 1937 & 1971 & 1893 & 1953 & 1944 & 1857 \\
\hline 180 days & 1991 & 1874 & 1888 & 1602 & 1769 & 1856 \\
\hline 360 days & 1971 & 2146 & 1894 & 1909 & 1767 & 1855 \\
\hline
\end{tabular}

was determined to be $2169 \mathrm{~m}$ /sec measured at the end of the third day after standing at room temperature for 48 hours at 70 ${ }^{\circ} \mathrm{C}$. The ultrasonic pulse velocity of the $\mathrm{C}$ class fly ash samples is given in Table 6 .

\subsubsection{Ultrasonic pulse velocity test results of class F fly ash specimens}

The ultrasonic pulse velocity of samples produced using the F class fly ash is shown in Table 7. All temperature cures of samples produced with the F-class fly ash and ultrasound transit rates in all age groups ranged from 1930 to $2661 \mathrm{~m} / \mathrm{s}$ (Table 7). The ultrasonic pulse velocity at the end of the third day of sample curing at room temperature amounted to 1930 $\mathrm{m} / \mathrm{s}$ after 48 hours of temperature curing at $50^{\circ} \mathrm{C}$. The highest ultrasound transit speed was $2661 \mathrm{~m} / \mathrm{s}$ at $90^{\circ} \mathrm{C}$ after 48 hours of temperature curing and at room temperature.

In general, it was established that the ultrasonic pulse velocity of samples containing the class $\mathrm{F}$ fly ash is higher than ultrasound transit rates of samples with the class $C$ fly ashes. It can be said that the reason for this is that the samples produced with the class C fly ash are of lower strength and lower unit weight than the samples produced with the F class fly ash. Also, the higher rate of vacancy of class C fly ash is understood by the ultrasonic pulse velocity, because the speed of sound is faster in solid than in space.

\subsection{Influence of water loss reduction during temperature cure on strength}

Some of the samples produced with the F class fly ash were subjected to temperature cure by using a heat resistant oven bag. The objective was to prevent the loss of water by putting the samples in a closed atmosphere. The flexural and compressive strength values obtained as a result of this study for preventing water loss are graphically shown in Figure 16. In order to test the effect of reducing water loss during temperature curing on the samples produced with the F class fly ash, the samples placed with the moulds were covered with oven bags so as not to breathe together with the mould. The method for preventing rapid water loss during temperature curing of samples caused flexural and increased compressive strength in specimens, especially at high temperatures. The specimens cured at $90^{\circ} \mathrm{C}$ for 96 hours exhibited the flexural strength of $10.62 \mathrm{MPa}$ and the compressive strength of 67.92 MPa. Trying to prevent water loss during thermal curing had a positive effect on flexural and compressive strength. It is believed that the reduction of water loss allows alkali ions in the sample to move more easily and quickly around the globe, thus easily reaching alkali ions that have not completed the geopolymeric reaction. In cases when water loss is not prevented, it can be said that the reaction of alkaline ions is prevented and the reaction can not reach the complete region in the samples where the water evaporates.

Table 7. Ultrasonic pulse velocity rates of samples produced with class F fly ash [m/s]

\begin{tabular}{|c|c|c|c|c|c|c|}
\hline Sample age & $50^{\circ} \mathrm{C}$ & $60^{\circ} \mathrm{C}$ & $70^{\circ} \mathrm{C}$ & $80^{\circ} \mathrm{C}$ & $90^{\circ} \mathrm{C}$ & $100^{\circ} \mathrm{C}$ \\
\hline 3 days & 1930 & 2209 & 2521 & 2473 & 2430 & 2001 \\
\hline 7 days & 2206 & 2283 & 2226 & 2459 & 2528 & 2054 \\
\hline 14 days & 1981 & 2302 & 2324 & 2525 & 2564 & 2579 \\
\hline 28 days & 2141 & 2141 & 2514 & 2504 & 2661 & 2514 \\
\hline 90 days & 2175 & 2250 & 2408 & 2573 & 2631 & 2587 \\
\hline 180 days & 2329 & 2342 & 2519 & 2579 & 2655 & 2650 \\
\hline 360 days & 2500 & 2413 & 2573 & 2585 & 2651 & 2641 \\
\hline
\end{tabular}




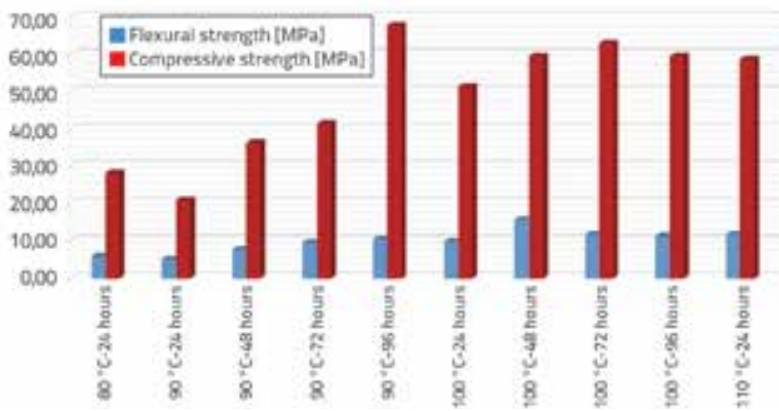

Figure 16. Effect of temperature curing on mechanical strength of samples cured in heat resistant oven bag.

\subsection{Microstructure Of Samples}

The scanning electron microscope (SEM) images of the sample subjected to 48-hour heat curing at $90{ }^{\circ} \mathrm{C}$ using the class $\mathrm{F}$ and class C fly ash are shown in Figures 17 and Figure 18, respectively.

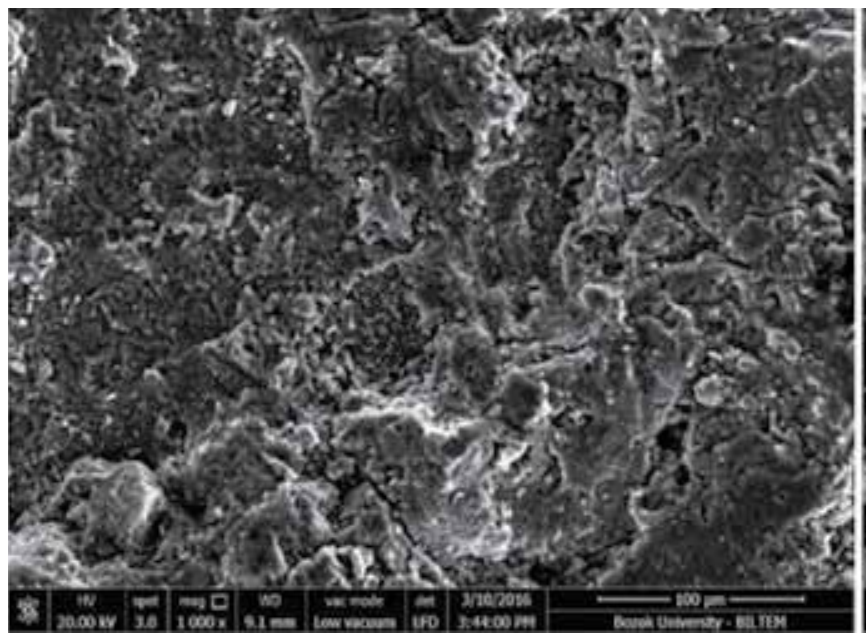

Figure 17. SEM images of sample F90
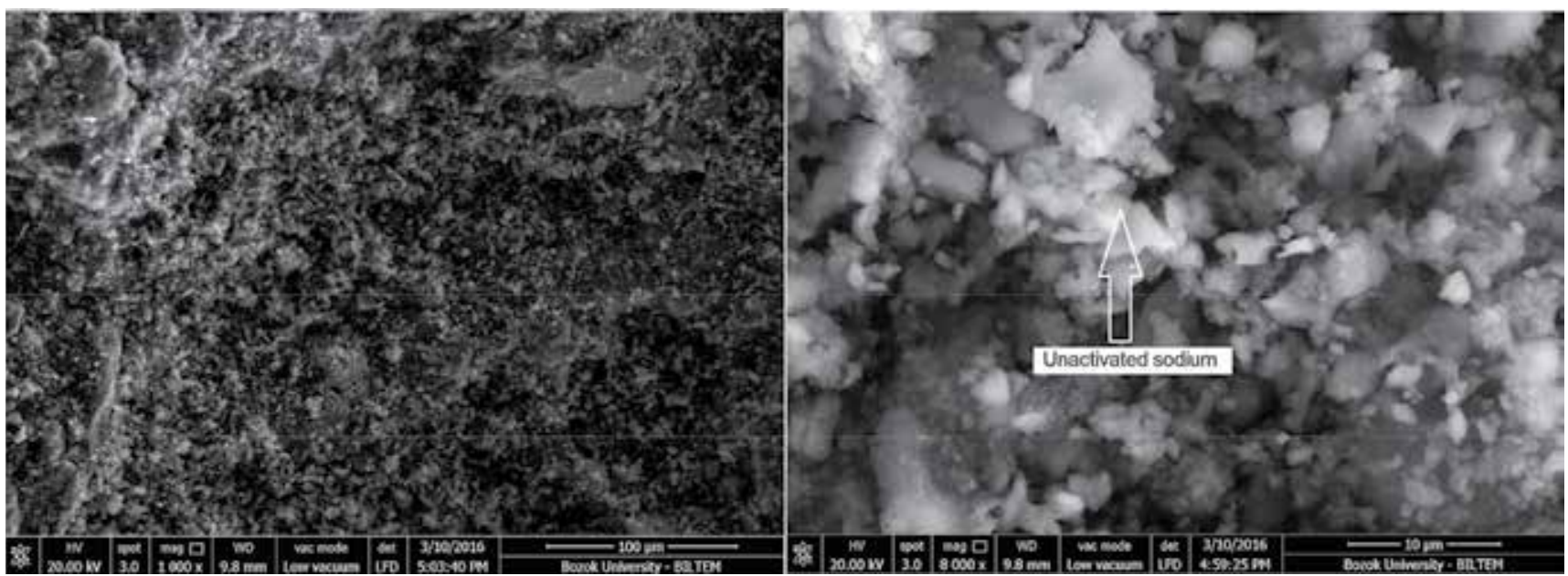

Figure 18. SEM images of sample C90

\section{Conclusions}

The following results were obtained from the laboratory study:

- Very satisfactory compression (in the order of $60 \mathrm{MPa}$ ) and flexural strength (in the order of $10 \mathrm{MPa}$ ) were obtained for geopolymer mortars produced with F class fly ash.

- It was observed that an increase in curing temperature of samples produced with the $\mathrm{F}$ class fly ash accelerates the geopolymerisation reaction. There is also an increase in strength of the $\mathrm{F}$ class ash-based mortars during the storage of the samples in laboratory environment after the thermal curing until the day of the experiment. Thus, the reactions continue at room temperature.

- Low compression strength (in the order of $15 \mathrm{MPa}$ ) and flexural strength (in the order of 1-3 $\mathrm{MPa}$ ) results were obtained for geopolymer mortars produced with the class C fly ash. Although the mortars produced with the class C fly ash exhibit an improved strength, they are dispersed in water when they are put into water for water absorption. For this reason, it is

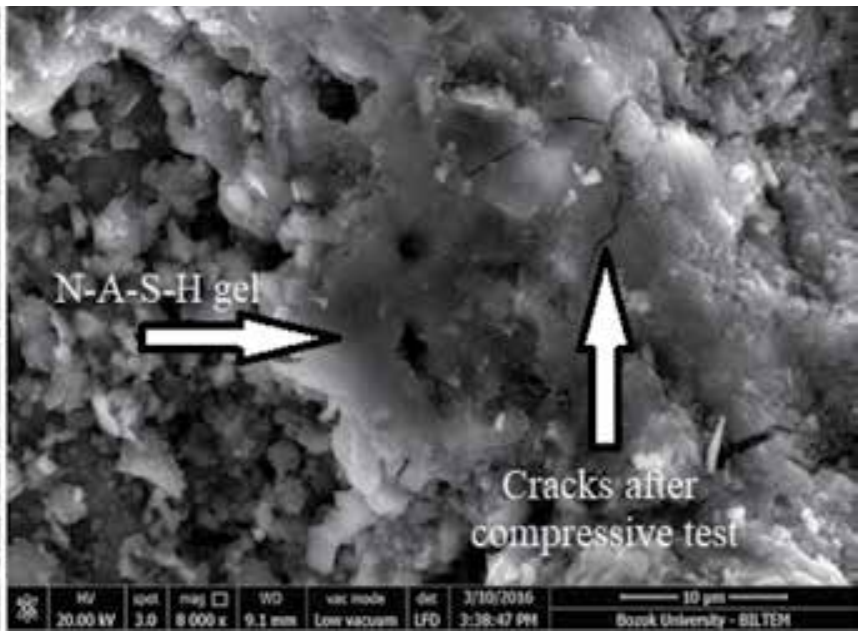


established that the mortars obtained from this column can not be used. The examination of the SEM images of the produced samples revealed that the $\mathrm{F}$ class fly ash used in the study reacted geopolymerically and the $\mathrm{C}$ class fly ash did not.

\section{REFERENCES}

[1] Engin, Y.: Sustainability - Leading Role in Concrete Innovation, Turkish Ready mixed concrete association, June (2016), pp. 74-76.

[2] The Europen Cement Association, 2016, Activity Report http:// www.cembureau.be, 12.10.2017

[3] General Directorate of Industry. Cement Sector Report, Turkey, 2015.

[4] Galzer, B., Graber, C., Rose, C., Syrett, P., Youssef, C.: Fly Ash in Concrete, http://transparency.perkinswill.com/Content/ Whitepapers/FlyAsh_WhitePaper.pdf, 05.04.2016

[5] ASTM C618-15, Standard Specification for Coal Fly Ash and Raw or Calcined Natural Pozzolan for Use in Concrete.

[6] Gamage, N., Liyanage, K., Setunge, S., Fragomeni, S.: Overview of different types of fly ash and their use as a building and Construction material, Proceedings of the International Conference of Structural Engineering, Construction and Management Kandy, Sri Lanka, 2011.

[7] Heidric, C., Feuerborn, H-J., Weir, A.: Cola Combustion Producta: a Global Perspective, World of Cola Ash (WOCA) Conference, Lexington, KY, April 22-25, 2013.

[8] Slaty, F., Khoury, H., Wastiels, J., Rahier, H.: Characterization of Alkali Activated Kaolinitic Clay, Applied Clay Science, 75-76 (2013), pp. 120-125, https://doi.org/10.1016/j.clay.2013.02.005

[9] Roy, D.M.: Alkali-activated cements Opportunities and challenges. Cement and Concrete Research, 29 (1999) 2, pp. 249-254, https:// doi.org/10.1016/S0008-8846(98)00093-3

[10] Davidovits, J.: Geopolymers and Geopolymeric New Materials, Journal of Thermal Analysis, 35 (1989) 2, pp. 429-441, https://doi. org/10.1007/BF01904446

[11] Duxon, P., Ferandez-Jimenez, A., Provis, J.L., Luckey, G.C., Palomo, A., Van Deventer, J.S.J.: Geopolymer technology: the current state of the art, Materials Science, 42 (2007), pp. 2917-2933, https:// doi.org/10.1007/s10853-006-0637-z.

[12] Zhang, Z.H., Zhu, H.J., Zhou, C.H., Wang, H.: Geopolymer from Kaolin in China: An overview, Applied Clay Science, 119 (2016), pp. 31-41, https://doi.org/10.1016/j.clay.2015.04.023

[13] Soutsos, M., Boyle, A.P., Vinai, R., Hadjierakleous, A., Barnett, S.J.: Factors influencing the compressive strength of fly ash based geopolymers. Construction and Building Materials, 110 (2016), pp. 355-368, https://doi.org/10.1016/j.conbuildmat.2015.11.045

[14] Petermann, J.C., Saeed, A., Hammons, M.l.: Alkali-Activated Geopolymers: A Literature Review, Air Force Research Laboratory Materials and Manufacturing Directorate Airbase Technologies Division, 2010.

[15] Badar, M.S., Patil, K., Bernal, S.A., Provis, J.L., Erez N.: Allouche Corrosion of steel bars induced by accelerated carbonation in low and high calcium fly ash geopolymer concretes, Construction and Building Materials, 61 (2014), pp. 79-89, https://doi. org/10.1016/j.conbuildmat.2014.03.015
- The F class fly ash performance was much higher than C class fly ash. Test results support this assertion. The prevention of water loss during thermal curing has a positive effect on strength.
[16] Khale, D., Chaudhary, C.: Mechanism of geopolymerization and factors influencing its development: a review, Journal of Materials Science, 42 (2007) 3, pp. 729-746, https://doi.org/10.1007/ s10853-006-0401-4

[17] Rangan, B.V.: Fly ash-based geopolymer concrete. Research Report GC 4, Engineering Faculty, Curtin University of Technology SF, Perth, Australia, 44 (2008).

[18] Barbosa, V.F.F., Mackenzıe, K.J.D., Thaumaturga, C.: Synthesis and characterization of materials based on inorganic polymers of alümina and silica: sodium polysialate polymers. International Journal of Inorganic Materials, 2 (2000), pp. 309-317, https://doi. org/10.1016/S1466-6049(00)00041-6

[19] Aydın, S.: Development of a Fiber Reinforced Composite with Alkali Activated Ground Granulated Blast Furnace Slag, Dokuz Eylul University, The Graudate School of Naturel and Applied Science, Civil Engineering Department, PhD thesis, 2010.

[20] KantarcI, F.: Investigation Of Fire Resıstance Of Geopolymer Concrete Produced From Elazığ Ferrochrome Slag By Alkali Activation Method, Inönü University Graduate School of Natural and Applied Sciences Department of Civil Engineering, Master of Science Thesis, 2013.

[21] Oh, J., Jun, Y., Jeong, Y.: Mechanical and microstructural dissimilarities in alkali-activation for six Class $\mathrm{F}$ Korean fly ashes. Construction and Building Materials, 52 (2014), pp. 396-403, https://doi.org/10.1016/j.conbuildmat.2013.11.058

[22] Görür, E.B.: Investigate the Strength and Durability Characteristics of Fly Ash Geopolymer Concrete with Alkaly. Erciyes University, The Graudate School of Naturel and Applied Science, Civil Engineering Department, PhD thesis, 2015.

[23] Changming, L., Tingting, Z., Lijiu, W.: Mechanical properties and microstructure of alkali activated Pisha sandstone geopolymer composites. Construction and Building Materials, 68 (2014), pp. 233-239, https://doi.org/10.1016/j.conbuildmat.2014.06.051

[24] Motorwala, A., Shah, V., Kammula, R., Nannapaneni, P., Raijiwala, D.B.: Alkali activated fly-ash based geopolymer concrete. International Journal of Emerging Technology and Advanced Engineering, 3 (2013) 1, pp. 159-166.

[25] Komljenovic, M., Bascarivic, Z., Bradic, V.: Mechanical and microstructural properties of alkali-activated fly ash geopolymers. Journal of Hazardous Materials, 181 (2010), pp. 35-42, https://doi. org/10.1016/j.jhazmat.2010.04.064

[26] Chi, M., Huang, R.: Binding mechanism and properties of alkaliactivated fly ash/slag mortars. Construction and Building Materials, 40 (2013), pp. 291-298, https://doi.org/10.1016/j. conbuildmat.2012.11.003

[27] Chi, M.: Effects of modulus ratio and dosage of alkali-activated solution on the properties and micro-structural characteristics of alkali-activated fly ash mortars. Construction and Building Materials, 99 (2015), pp. 128-136, https://doi.org/10.1016/j. conbuildmat.2015.09.029 
[28] Kaya, M.: Examination of Mechanical and Durability Properties of Various Types of Fly Ash Produced by Using Alkali Activated Mortars, Sakarya University, The Graudate School of Naturel and Applied Science, Civil Engineering Department, PhD thesis, 2016.

[29] Görhan, G., Kürklü, G.: The influence of the $\mathrm{NaOH}$ solution on the properties of the fly ash-based geopolymer mortar cured at different temperatures, Composites Part B: Engineering, 58 (2014), pp. 371-377. https://doi.org/10.1016/j. compositesb.2013.10.082

[30] Arrifin, M.A.M., Bhuatta, M.A.R., Hussin, M.W., Tahir, M.M., Aaziah, N.: Sulfuric acid resistance of blended ash geopolymer concrete. Construction and Building Materials, 43 (2013), pp. 80-86, https:// doi.org/10.1016/j.conbuildmat.2013.01.018

[31] Nikolic, I., Karanovic, L., Castvan, I.J., Radmilovic, V., Mentus, S., Radmilovic, V.: Improved compressive strength of alkali activated slag upon heating. Materials Letter, 133 (2014), pp. 251-254, https://doi.org/10.1016/j.matlet.2014.07.021

[32] Ma, Y., Ye, G.: The shrinkage of alkali activated fly ash. Cement and Concrete Research, 68 (2015), pp.75-82, https://doi. org/10.1016/j.cemconres.2014.10.024

[33] Özodabaș, A., Yılmaz, K.: Improvement of the Performance of Alkali Activated Blast Furnace Slag Mortars with Very Finely Ground Pumice, Construction and Building Materials, 48 (2013), pp. 26-34, https://doi.org/10.1016/j.conbuildmat.2013.06.047

[34] Tippayasam, C., Balyore, P., Thavorniti, P., Kamseu, E., Leonelli, C., Chindaprasirt, P., Chaysuwan, D.: Potassium alkali concentration and heat treatment affected metakaolin-based geopolymer. Construction and Building Materials, 104 (2016), pp.293-297.

[35] Duan, P., Yan, C., Zhou, W.: Influence of partial replacement of fly ash by metakaolin on mechanical properties and micro structure of fly ash geopolymer paste exposed to sulphate attack. Ceramic International, 42 (2016), pp. 3504-3517, https://doi. org/10.1016/j.ceramint.2015.10.154
[36] Atiș, C.D., Gorur, E.B., Karahan, O., Bilim, C., Illkentapar, S., Luga, E.: Very high strength (120 MPa) class F fly ash geopolymer mortar activated at different $\mathrm{NaOH}$ amount, heat curing temperature and heat curing duration, Construction and Building Materials, 96 (2015), pp. 673-678, https://doi.org/10.1016/j. conbuildmat.2015.08.089

[37] TS EN 196-1:2005: Methods of testing cement - Part 1: Determination of strength.

[38] TS EN 1015-3: Methods of test for mortar for masonry- Part 3: Determination of consistence of fresh mortar (by flow table)

[39] TSEN 1250-4: Concrete tests - Part 4: Determination of ultrasonic pulsed wave velocity.

[40] TS EN 1015-11: Methods of test for mortar for masonry- Part 11: Determination of flexural and compressive strength of hardened mortar.

[41] Indu, D., Elangovan, R.: Study and Manufacture of Geopolymer Concrete using Class C type Fly Ash, International Journal of Engineering Trends and Technology (IJETT), 37 (2016) 6.

[42] Wan Mastura, W.I., Kamarudin, H., Khairul Nizar, I., Mustafa Al Bakri, A.M., BnHussain, M.: Effect of Curing System on Properties of Fly Ash-Based Geopolymer Bricks, Advanced Materials Research, 626 (2013), pp. 937-941, https://doi.org/10.4028/ www.scientific.net/AMR.626.937

[43] Atiș, C.D., İlkentapar, S., Görür, E.B., Karahan, O.: Activated Fly Ash on Mechanical Properties of the mortar with alkali Geopolim The Effect of Heat Curing Time, 9. Concrete National Congress, Antalya, Turkey, 16-18 (2015) 1, pp.1-9

[44] İlkentapar, S., Atiș, C.D., Karahan, O., Görür Avșaroğlu, E.B.: Influence of duration of heat curing and extra rest period after heat curing on the strength and transport characteristic of alkali activated class $\mathrm{F}$ fly ash geopolymer mortar, Construction and Building Materials, 151 (2017), pp. 363-369, https://doi. org/10.1016/j.conbuildmat.2017.06.041 